\title{
A Study on Need and Constrains of Women Entrepreneurs in Dakshina Kannada
}

\author{
Laveena D’Mello ${ }^{1}$, Meena Monteiro ${ }^{2}$, \& Govindaraju B. M. ${ }^{3}$ \\ ${ }^{1}$ Assistant Professor, Social Work Department, Srinivas Institute of Management Studies, \\ Mangalore, Karnataka, INDIA. \\ ${ }^{2}$ Associate Professor, MSW Department, School of Social Work, Roshni Nilaya, Mangalore, \\ Karnataka, INDIA. \\ ${ }^{3}$ Assistant Professor, Dept. of Sociology, Mangalore University, Karnataka, INDIA. \\ E-Mail: lavynoronha@gmail.com
}

Type of the Paper: Research Article.

Type of Review: Peer Reviewed.

Indexed In: OpenAIRE.

DOI: http://dx.doi.org/10.5281/zenodo.833483.

Google Scholar Citation: $\underline{\text { IJCSBE }}$

How to Cite this Paper:

D’Mello Laveena., Monterio, Meena., \& B. M. Govindraju. A Study on Need and Constraints of Women Entrepreneurs in Dakshina Kannada. International Journal of Case Studies in Business, IT and Education (IJCSBE), 1(2), 14-21.

DOI: http://dx.doi.org/10.5281/zenodo.833483.

International Journal of Case Studies in Business, IT and Education (IJCSBE)

A Refereed International Journal of Srinivas University, India.

(C) With Authors.

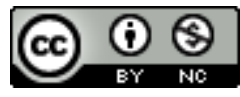

This work is licensed under a Creative Commons Attribution-Non Commercial 4.0 International License subject to proper citation to the publication source of the work.

Disclaimer: The scholarly papers as reviewed and published by the Srinivas Publications (S.P.), India are the views and opinions of their respective authors and are not the views or opinions of the S.P. The S.P. disclaims of any harm or loss caused due to the published content to any party. 


\title{
A Study on Need and Constrains of Women Entrepreneurs in Dakshina Kannada
}

\author{
Laveena D’Mello ${ }^{1}$, Meena Monteiro ${ }^{2}$, \& Govindaraju B. M. $^{3}$ \\ ${ }^{1}$ Assistant Professor, Social Work Department, Srinivas Institute of Management Studies, \\ Mangalore, Karnataka, INDIA. \\ ${ }^{2}$ Associate Professor, MSW Department, School of Social Work, Roshni Nilaya, Mangalore, \\ Karnataka, INDIA. \\ ${ }^{3}$ Assistant Professor, Dept. of Sociology, Mangalore University, Karnataka, INDIA. \\ E-Mail: lavynoronha@gmail.com
}

\begin{abstract}
Women prefer to work part time job than full time because of various constraints, who have more family responsibility than male. They suffer from low salary, unemployment which lead them lower status in the society. This paper undertakes the study on the needs and constraints of women entrepreneur. And explore the relevance of self-employment, training, and motivate to start self-employment and to become a successful entrepreneur. The aim is to give detail picture about the need and constraints of women entrepreneurs in Dakshina Kannada. And the objectives are: To study the profile of the respondents; To explore the relevance of training, focussing on the factors responsible for relative success and failure of self employment; To identify the Social and Economic condition of the respondents before and after starting Self Employment; To know the impact of Self Employment training and the constraints to become successful entrepreneurs and the measures to overcome the problems. This is the descriptive study conducted in Dakshina Kannada District. The sampling consisted of 50 self-employed urban women and was selected through the accidental and snow ball sampling method.
\end{abstract}

Keywords: Entrepreneur, women, self-employment, training and income generation.

\section{INTRODUCTION :}

Employment is often described as the most important link between economic growth and poverty reduction. Providing income earning opportunities through wage employment or self-employment for poor women and men is crucial to raising incomes and overcome poverty. However, currently, women across the developing world enjoy limited access to fair and decent work compared to men. In a patriarchal society such as Indian traditional society, there exists the unfounded belief that man is the breadwinner of the family. Consequently, the male child gets the best of the limited facilities and resources with the family. The girls are deprived of school education because she has to take care of siblings at home and since she is to be married off soon; investing in her education is liabilities, not an asset. Despite this fact that women are massively involved in agriculture, food production and the like, their work counts for nothing. Their activities as producers are not reflected in statistics, thus making their contribution invisible. Culturally, in an effort to uphold cultural heritage, the past is glamorized and with it, the trend to equality of women and enhancement of their role in development gets inhibited. The role of women in overall development has not been fully understood nor has it been given weight age in the struggle to fight poverty, inequality, and injustice. [1, 2]

\section{THE SITUATION :}

Women in our society are working and are engaged in some regular economic activities. The majority of these women are acutely underemployed- their wages are low, the work is not adequate and yet they must work in order to bring in some real or monetary income every day. These women 
are often the sole supporters or primary bread winners in their family. It is their income which provides the survival for the family. Women have an important role in conditioning the family life. The majority of women take the work for an economic reason because of the economic compulsions of the family. Women are required to take up a job outside the family. The majority of the women attach the reason for their taking up a job outside the home to supplement family earnings. The educated women too are facing similar kind of problems and have the number of roles to play in their life. They have minimum five duties in their life. Firstly to work outside and earn income, Secondly to take care of their children, their needs, Thirdly the house work like cleaning, washing, cooking etc, Fourthly to teach the children values and their education, home work, projects, tuition at home additional teaching etc to learn better and Fifthly to take care of the dependent members like sick and old in the family. While comparing the highly educated and moderately literate women, the women, it is the educated women who suffer more [3, 4]. Generally speaking, employed women will have the courage to face any kind of difficulties and challenges in life. It is how she will manage the whole situation individually is a question and consider herself as super women. It is very much taxing for women employees to work outside for others; especially they have to travel a long distance every day and also to maintain time. Self-employment or small entrepreneurship, your own business is a greater relief for some who have many dependents like very young children and old people in the family [5].

\section{THE PLIGHT OF WOMEN :}

For most women, the aim of taking up employment is a higher standard of living for their families. It was clear to them that with two earning members in the family a standard of living were becoming possible that had never been within the reach of these families before. It was also the companionship with other women to improve the social life. But in our society, it is common knowledge that women have limited access to positions of power and influence; they have fever occupational choices and are, in fact, valued for their reproductive role. In many parts of the society, they still lack access to education and training, to health and family planning services and to information and resources. Their legal standing is inferior to men and they are unable to participate in government and politics. The working women have to face several problems in the course of her family life as well as working women. Because of her taking up a job outside her home she may not be in a position to devote that much amount of attention towards her husband, children and family members that she is actually supposed to devote as a house wife. Because of economic necessity, it may not be within her reach to employ full-time servants. If she carries out the entire traditional roles single handed at home attend the duties and responsibilities at her job, she overstrains herself and finds herself constantly in a tired and imitable state of body and mind and this may not be a pleasurable company to her husband, children, and family members. On the other hand, if she fails to carry out efficiently her role as a wife and mother, she will be accused of being inefficient and vain and she also suffers from guilty conscious and finds herself torn between home and work. If there is no cooperation, understanding, and adjustment from the husband and other family members the marital frictions and family tensions arise and create social and psychological as well as enter personal and interpersonal problems at home. Because of this tension and factions at home, she may also fail to present herself as an efficient and effective personality at her employment.

\section{SOME ISSUES :}

Those working with women and girls are faced with many issues and questions, such as these: Must women and girls have a say in decisions which affect their lives or should they always be subject to others, especially men?; Should women work outside the home? Most women work at home, but many from low-income families are compelled to work outside the home also for survival. The lower-middle-class women take up jobs to make ends meet. This question, therefore, is irrelevant for women and men from poor families; If women are forced to work at home and outside, should they continue to carry a double burden or should society find ways of relieving them of their burden?; Will men give a helping hand to women in child rearing and household tasks of not forced by circumstances? Will Indian women discourage boys from learning housekeeping jobs which will lead to their non-participation as adults?; To get a sense of fulfilment, should women confine themselves to the home and family or broaden their vision and venture into new fields of endeavour such as self- 
employment or technology?; Whatever the choice, women in their struggle for emancipation should not underestimate the intelligence, the planning, and management skills that are required to run a home efficiently. If a job is to be added on, an organization of effort and economy of time will have to be considered. Therefore if any women choose to be a home-maker primarily and accomplish her role satisfactorily, she should be justly proud of the contribution she makes to her family and society. In addition, if she contributes to the family income her increased contribution must be recognized.[6]

\section{WOMEN NEED INCOME :}

Poor women in village and town areas have to earn a living or supplement the income of their family. Therefore it is important for girls and women to prepare themselves for it psychologically by learning skills and obtaining the knowledge and information related to resources. The women need employment for many reasons. Firstly, Women do not often own land or they have no legal rights to use it. They are easily evicted from the land at the time of divorce, desertion, and widowhood. If they own land, they are sometimes deprived of it by brothers, uncles, and in-laws. Secondly, Women workers get fewer wages than men and are more likely to be unemployed, because they are unskilled. They are also discriminated when it comes to wages, hours of work etc. The problem of the educated women is also no much difference. They too suffer from the discrimination of the salary, increment, promotion and getting responsibility at their work place. Even though employment opportunities are more for women and preference is given to them, there is discrimination in all aspects. Women are more concerned with the needs of the family and spend their income for their nutritious food. All these factors make it important to expand income generating employment for women so that they have earnings in cash or kind on which they can have control.

\section{CHALLENGES OF WOMEN ENTREPRENEURS :}

Prior to 1975, women entrepreneurs were not given much importance in the state. When the United Nations declared 1975 as the International Women's Year, the approach to women entrepreneurs began to change, and the government announced various schemes to bring women into the mainstream of industries. Many training programs were organized; covering various aspects of modern management techniques, project implementation etc. Over a period of time, banks have put in several efforts to help economic development in the country and in that process banks have given more attention to beneficiaries, particularly to the men folk. However, in recent past, the bank has been specially bestowing their attentions on the needs of women entrepreneurs. However, experience reveals that following are the areas which inhabit women beneficiaries to become entrepreneurs and set up their economic units through bank finance: and they are lack of motivation and confidence, Lack of full knowledge about available business particulars, Lack of complete information with regard to collection of environmental data for formatting business plan, Lack of appropriate information about procedure of various institutions, requirement and sources of assistance for this purpose and Lack of managerial competence to run manufacturing/processing units on sound principles of business managements [7].

\section{INCOME GENERATION AND HOME INDUSTRIES :}

Therefore what are some of the income-generating activities that can be introduced into the nonformal education programs or self-employment training for women? This is vital for the success of the program/training because the results of income generating efforts can be seen and measured. Therefore women participate in large numbers of education, training and income generation go hand in hand. Income generating programs can be planned for women, which required skill, training, production, and marketing. On a small scale, women can individually, with the family or with the community or group venture into the production of goods and can be sold in the local market or sent to the cities. Depending on the raw material available, training in skills could be imparted to women and girls to enable them to produce these items of good quality for sale [8,9]. Examples of a few items that could be manufactured are: Mats, brooms, baskets; Beed work or rope making from grass fibre; Pickles, jams, preserves,; Tomato-sauce, peanut-butter and chutneys; Papads, masala powders and dried herbs; Butter, cheese, sour milk, curd, Snacks and sweets; Garments, knitted goods and laces; Candle making; Bakery items/eatables; Chemical products; Screen printing; Handicrafts and 
tailoring. This list can be vastly expanded based on raw materials available, skill to be acquired and a ready market that can be guaranteed.

\section{TRAINING -CUM-PRODUCTION :}

Women have skills that are required for home management, which involves making things for the family and the house. They make mats, Baskets, brooms articles out of grass and reed during their leisure hours particularly for use at home. Since they have these skills, they need not undergo training to produce these in large numbers for sale. Sauces, pickles, snacks, and sweets are also made for home use. However, when preparing these in large quantities other skill will be required such as buying raw material at the cheapest rates, proper storage to reduce destruction by insects, maintaining good quality and standards to attract buyers, making sure of a market before venturing out to produce the goods and keeping accounts. For purpose of training women for self-employment, government, NGO's, SHG's, Banks, UGC grant programs have introduced.

\section{WELFARE SCHEMES FOR THE ECONOMIC PARTICIPATION OF WOMEN :}

Evaluation of many of the economic schemes has revealed that the provision of small micro opportunities for women, which are usually classified as income generating projects, can make only a marginal dent on the strong and wide spread need of women for gainful employment. Thus it is in mainstream agriculture, non-farm rural employment, including construction, and in the industry and services sector. Especially as self-employed, those women have the basic opportunity for income earning. Most of the studies on the issues of women's employment have pinpointed the importance of organizing women workers. Trade unions, usually dominated by men, have not taken as much interest in the unionization of women workers. Yet those who have successfully organized women workers have found that this has not only strengthened and increased women's income through wage struggles and by the provisions of backward and forward linkages but has also provided focuses for opinion formations.

\section{EDUCATION AND TRAINING OF WOMEN :}

If women have to be a part of the mainstream of future development, new avenues would have to be thrown open to them. There would have to be an up gradation of skills. Technical, financial and marketing supports would have to be extended to them. There would not only have to be a large investment in their training but the training itself would have to be far more innovative and diverse in character. Vocational training institutes tend to concentrate their curriculum for women in activates such as cutting and sewing, secretarial services and beauty care. Organization working with the poorest women have pointed out how the majority of rural and urban women prefer to be trained in more demand oriented skills like watch repair, chemical products, electrical goods repair, candle making, Motor rewinding etc. [10-12].

\section{MAJOR FINDINGS OF THE STUDY :}

The finding of the research is in the line with the objectives of the study as stated earlier in chapter III. Apart from the declared objectives, the research has been able to bring out certain secondary aspects, which was no perceived /anticipated while initiating the study. The details of the findings are summarized here below.

Profile of the respondent: Most of the women who underwent training are above the age group of 35years, which definitely highlights their experience and maturity. The majority of the women belong to Hindu religion, a considerable number of Christian and in the study nobody is formed other religions which are also indicating due to cultural factor may be women are not got an opportunity to join any NGO's or SHG's. Urban Women all are literate and have got a basic formal education. In the study, no body was found illiterate. Most of them completed their SSLC and PUC level education. They have the knowledge about money lending rate of Interest of Bank and other business transactions and regarding marital status, eighty-four percent of the women are married. This again highlights their interest in gaining income for their family based on increased need of the family. The majority of the women (74\%) have four to six members in their family and $82 \%$ of the women from a nuclear family. 
The relevance of training focussing on the factors responsible based on relative success and failure of self employment: Most of the women $88 \%$ attended one or two training programmes and they attended short term training 30\% of them attended training between eleven days and 30 days and everyone expressed that they are happy with the training they received which included both theory and practical. About $54 \%$ of the respondent completed their self-employment training year back and they have started self-employment while those who completed the training recently within three months are going to start employment and these groups' investment and profit are very low while compared to those who have completed a year. NGO's have taken more initiated to organize these training. And Forty percent of the respondents received training from the NGO's. This NGO's not only taking interest in pertaining training but also in providing seed money to start self-employment through SHG's. It also gives avenues to sell their products through organizing meals (marketing goods), Production units etc., almost all the trades were undergone by the respondent based on their interest. Not only the trades which were exclusively taken by them but even other trades which were taken by only men now women have taken interest in that. The Electrical goods, motor rewinding, Home appliance maintenance, and repair work was taken by women. Few women involved in manufacturing emergency lights and they say it is more profitable. About Ninety-six percent of the respondent who completed their training have ventured to start self-employment which indicates that they were provided not only training but also motivated, assisted in starting self employment. The occupation of the respondent was the housewife (66\%). And these respondents never involved in any other income generating employment. They were just doing the household work which they never earned anything. The study indicates that these women who have never involved in any activities before training have started the self-employment after the training. About $94 \%$ of the women started self-employment. Which shows the training they receive was successful. The monthly income before self-employment training is not applicable to $66 \%$ of the respondents since they were a housewife. But the monthly income after the training program there is a gradual increase in the income. $32 \%$ of the respondents have income more than Rs. 3,001.00. And few have income between Rs. 35,000.00 to Rs. 70,000.00. This also highlights more they invest more profit. And women who have started self-employment in small scale will have less income.

Economic condition: Sixteen percent have income more than Rs. $14,000=00$ per month. The average Monthly income of the family members is Rs. 6,001=00 - Rs. 8,000=00 (20\%) which shows that the respondents belong to the lower middle class and economically poor people who go for these selfemployment training. Generally, people spend money based on their income. And part of their income will be saved for the foreseen and future security. The average expenditure is Rs. $6,001=00-$ Rs. $8,000=00$ (26\%) and the sixteen percent of the respondents have expenditure above Rs.10,000 $=00$ This can be concluded that as income grows the expenditure will also will go up. About $94 \%$ have the saving habit and $72 \%$ also have debt. They repay the loan regularly and a small portion of their income they save. They get a loan from varies source and the major source is SHG and Banks. And 28\% of the respondents do not have any loan. They save in SHG, Banks and Post office. Their saving amount is very less. About $42 \%$ save less than Rs. $300=00$ per month. Six percent do not save any money and $10 \%$ save more than Rs. 2,000=00 per month.

Social condition: $72 \%$ of the respondents are staying in their own house. $64 \%$ in tiled house and the condition of the house is satisfactory and good. All most all the respondents have Toilets and electrification. And also have three to four rooms in their house. They have facilities for pure drinking water supply either they have their own well or the Municipal pipe line. These are the entire indicator that their housing condition is satisfactory. The women expressed their family members support to assist them in their house hold chores as well as in income generating activities (88\%). About 58\% have support for their production of goods. And 56\% expressed that they have support for marketing of the goods too from the family members. In an urban area, the women have support from the family members. Some other cases the employment women chosen are the skill based so it is difficult for the family members to support them in their employment. The health condition of the women is normal. About $56 \%$ do not have any ailments and few have other psychological related and work based ailment like minor problems like back ache, headaches joint pains etc. Four percent of the respondents were handicapped. Eighty-one percent of the respondent does not have any workers 
to help in the production or income generating activities. This shows the investment amount is very low. And the family as a unit involved in this activity.

\section{CONCLUSION AND SUGGESTIONS :}

In the light of the findings of the study and within the limits set down in terms of representativeness, the following conclusions and suggestions may be drawn. It is generally women who have to leave a job or agree to work for less salary. This is due to her responsibility at home to take care of children and if she has old and sick dependents at home to look after. If she has a skill which she has learned she can earn money by self. This will make her economically independent and self-sufficient which in turn will increase her self-esteem. Religion should not be a barrier for women in taking selfemployment training. The study highlights more opportunities for Hindu and Christian women as compared to Muslims and other caste women. So the organizers of this type of training should give more importance to minorities not only in the selection, giving training and awareness but support them financially and do proper follow-ups.

Self-employment training can be given in one or two trades and advanced training on same trades will help women rather than training in various fields. Regarding the duration of training, it is not at all important. All the respondents are happy with the training they received. It is suggested Quality is more important than the Quantity which makes women more courageous. At the beginning stage of self-employment women have to face many problems like low self-esteem, seed money, marketing, a place for production, adjustment of the family members etc, But later they have overcome all these hurdles for some extent and become successful. It is naturally difficult for any women to start new venture alone without the support of others, so family members, organizations, NGO's and especially the SHG's have to support them at the beginning stage of self-employment.

Many organizations have come forward to improve the status of women and empower them financially by providing free training like NGO's. GO's, Banks and Private Sectors. They do give training but what is seen is the lack of follow up. It is suggested if they do a follow-up of the training, there can be remarkable changes in women's initiative to take up self-employment. Bias at work often prevents women from joining certain types of education and training. Appropriate training facilities would be initiated for the skill development of women job seekers to promote their employability including self-employment. There are plenty of trades. Depending on the raw materials available, the interest of the women they can select and start self-employment in any fields. Women have to change the ideas of preparing only papad and pickle because there are many other trades which are available for them which once were considered exclusively for men. The major trades which women in the study have ventured are the maintenance of Home appliances, motor winding, electrical goods manufacturing, electronic items etc which they can start without much investment. They have also started other skill based employment with less investment like Beautician, tailoring etc which is more profitable[18].

There are changes in the economic status of the women after starting self-employment but changes are a minute. This is because women mainly are scared to take more risk. They invest less and get less profit. Women should be supported to invest more so that they can earn more. The women who perceive self-employment may be from lower middle-class families or even from poor families. But these Urban women respondents enjoy all the basic facilities like good housing, electricity, drinking water etc., and the living condition has also improved. The majority of them have full support from the family members. They enjoy good health and only a few have a minor ailment which is due to physiological and psychological problems.

The proper share for women in economic growth in terms of employment and production opportunities would bestow economic independence to our women. Economic independence of women, in turn, will result in improving the social status and living conditions of women. Therefore the public sector banks, NGO's and industrial finance corporation have a great responsibility in developing women entrepreneurship through the provisions of finance and technical guidance in our country. The growing female unemployment and poverty in India can also be tackled effectively by the way of developing women entrepreneurship. The progress attained in creating entrepreneurship among young women would enable them to attain socio-economic equity and contribute their mite to the prosperity of the nation. 


\section{REFERENCES :}

[1] D’Mello Laveena (2017). NGO’s Intervention to Bring Change in the Society- A Case Study of 'SIRRA'. International Journal of Case Studies in Business, IT and Education (IJCSBE), 1(1), 19-26. DOI: http://dx.doi.org/10.5281/zenodo.580084.

[2] Monteiro Meena, D’Mello Laveena, B. M Govindaraju (2017), A Study on the Working Conditions of Sales Persons in a Garment Shop at Mangalore. International Journal of Case Studies in Business, IT and Education (IJCSBE), 1(1) http://dx.doi.org/10.5281/zenodo.584118.

[3] Desai Vasanth (2017). Development of New Enterprises. Himalayan Publishing House, First edition, ISBN 978-93-5273-027-8.

[4] Moorthi C.S.V. (2017). Small scale industries and entrepreneurship. Himalayan Publishing House, ISBN 978-93-5273-056-8

[5] Desai Vasanth (2011). Small scale industries and entrepreneurship. Himalayan Publishing House. Ninth Edition, ISBN-13: 978-9350248621

[6] J.C. Saboo Megha Biyani (2009) Management of small scale industries, Himalayan Publishing House.

[7] R. Gopal, Manjrekar Pradip (2017). Change makers (Role of Entrepreneurship Management). Himalayan Publishing House.

[8] Moharanas and Dash C.R., (2013). Factors influencing entrepreneurial development and motivation. RBSA Publishing, Jaipure.

[9] Moharanas and Dash C.R. (2017) Entrepreneurship development. RBSA Publishing, Jaipure.

[10] Collins and Lazier W (1992). Beyond entrepreneurship. Prentice Hall, New Jersey.

[11] David Oates (2009). A Guide to Entrepreneurship. Jaico Publishing House, Mumbai.

[12] Collins and Lazier W (1992). Beyond entrepreneurship. Prentice Hall, New Jersey’

[13] Austin, J.E., Gutierrez, R., Ogliastri, E. \& Reficco, E. (2007). Capitalizing on convergence. Stanford Social Innovation Review.

[14] Brown, L.D. \& Letts, C.W. (2004). Social entrepreneurship \& societal transformation: An exploratory study Journal of Applied Behavioral Science, 40, (3), 260-82 .

[15] Austin, J.E. (2006). Three avenues for social entrepreneurship research. In J. Mair, J. Robinson \& K. Hockerts (eds), Social Entrepreneurship. Basingstoke: Palgrave Macmillan pp. 22-33.

[16] Bornstein, D. (2007). How to Change the World: Social Entrepreneurs and the Power of New Ideas (Updated Edition). New York: Oxford University Press Inc.

[17] Austin, J., Stevenson, H. \& Wei-Skillern, J. (2006). Social and commercial entrepreneurship: Same, different, or both? Entrepreneurship theory and practice, 30, 1: 1-22

[18] Monteiro Meena, D’Mello Laveena, B. M Govindaraju (2017), A Study on Quality of Life among Working Women with High Blood Pressure. International Journal of Management, Technology, and Social Sciences (IJMTS), 1(1) 74-81, http://dx.doi.org/10.5281/zenodo.583742. 